\title{
Testing the Effect of Snag and Cavity Supply on Deadwood-Associated Species in a Managed Boreal Forest
}

\author{
Samuel Dufour-Pelletier ${ }^{1,2, *}$, Junior A. Tremblay ${ }^{3}{ }^{\circledR}$, Christian Hébert ${ }^{4}{ }^{\oplus}$, Thibault Lachat ${ }^{5,6}$ \\ and Jacques Ibarzabal ${ }^{1}$ \\ 1 Département des Sciences Fondamentales, Université du Québec à Chicoutimi, \\ 555 Boulevard de l’Université, Chicoutimi, QC G7H 2B1, Canada; jacques_ibarzabal@uqac.ca \\ 2 Bureau Environnement et terre d'Odanak, Conseil des Abénakis d'Odanak, 104 rue Sibosis, \\ Odanak, QC J0G 1H0, Canada \\ 3 Science and Technology Branch, Environment and Climate Change Canada, 1550 Avenue d'Estimauville, \\ Québec, QC G1J 0C3, Canada; junior.tremblay@canada.ca \\ 4 Laurentian Forestry Centre, Natural Resources Canada, 1055 rue du P.E.P.S., Québec, QC G1V4C7, Canada; \\ christian.hebert@canada.ca \\ 5 School of Agricultural, Forest and Food Sciences HAFL, Bern University of Applied Sciences, Länggasse 85, \\ 3052 Zollikofen, Switzerland; thibault.lachat@bfh.ch \\ 6 Swiss Federal Research Institute WSL, Zücherstrasse 111, 8903 Birmensdorf, Switzerland \\ * Correspondence: samuel.dufour@hotmail.fr
}

Received: 16 March 2020; Accepted: 4 April 2020; Published: 9 April 2020

\begin{abstract}
Standing deadwood is an important attribute of old-growth boreal forests and it provides essential microhabitats for deadwood-associated species. In managed boreal forests, short rotations tend to limit the amount and diversity of standing deadwood. This study evaluates if the anthropogenic supply of deadwood attributes through tree girdling or by providing nest boxes may favor deadwood-associated species. We studied the short-term response of saproxylic beetles, foraging woodpeckers, and secondary cavity users to snag and cavity supply in 50 to 70-year-old black spruce stands. In spring 2015, we girdled 8000 black spruce according to two spatial distributions (uniform and clustered), and we also installed 450 nest boxes of six different sizes at three distances from the forest edge. Using trunk window traps, we captured significantly more beetles in sites with girdled trees than in control sites in both 2015 and 2016. We also recorded a trend of a greater abundance of beetles in clusters of girdled trees than within uniformly distributed girdled trees. Trypodendron lineatum (Oliver) dominated beetle assemblages, representing $88.5 \%$ of all species in 2015 and $74.6 \%$ in 2016. The number of beetles captured was 7× higher in 2015 than in 2016. In contrast, we observed greater amounts of woodpecker foraging marks in fall 2016 than in either fall 2015 or spring 2016. Woodpeckers foraged significantly more in clusters of girdled trees than within uniformly distributed girdled trees. Woodpeckers' foraging mark presence was positively associated with the proportion of recent cuts at $1 \mathrm{~km}$ around the study sites. Five Boreal Chickadee (Poecile hudsonicus Forster) pairs used nest boxes and occupied smaller box sizes that were located away from the forest edge. Our study showed that structural enrichment can be effective in rapidly attracting deadwood-associated species within managed forest stands.
\end{abstract}

Keywords: deadwood; cavity; woodpeckers; saproxylic insects; nest box; Trypodendron lineatum

\section{Introduction}

The overall landscape and age structure of eastern Canadian boreal forests have been altered by forest harvesting [1,2], thereby inducing changes in the amount and diversity of standing deadwood [3]. 
Indeed, the time elapsed between rotations does not allow the recovering of deadwood structures that are normally found in old-growth boreal forests [4]. Management and conservation targets implemented in recent decades have proven to be insufficient in preventing habitat losses below minimum ecological thresholds [5]. Moreover, salvage logging after natural disturbances removes substantial amounts of deadwood in most accessible areas [6]. In Fennoscandia, several species of plant, animal, and fungus are now threatened by the rarefaction of deadwood attributes resulting from long-term intensive forestry [7]. Given the similarities in forest-age structure and bird assemblages of Fennoscandian and northeastern Canadian boreal forests [8], it is important to implement management practices that will avoid such an outcome in Canada.

Ecosystem-based forest management has emerged as a means of reducing the negative effects of forestry on ecosystems [9]. By emulating natural disturbances (e.g., wildfires, insect outbreaks, windthrows), it is expected that managed forests will maintain forest structures within their historical range of natural variability. In turn, this would help in maintaining the boreal fauna that have evolved under natural disturbance regimes. Forestry practices aiming to increase the diversity of forest structures and promote the availability of different types of deadwood could be an asset for the conservation of deadwood-associated species, also called saproxylic species [4,10].

Many vertebrates and insects rely on standing deadwood (hereafter referred to as snags) during some part of their life cycle [11,12]. By digging galleries under the bark or into the sapwood of recently dead trees, some aggregative beetles such as scolytids (Curculionidae) have a critical effect on the dynamics of other species that use snags as a foraging substrate [13]. These associations, however, may differ according to the type of deadwood produced [14]. Indeed, the Black-Backed (Picoides arcticus Swainson; hereafter BBWO) and the American Three-Toed (Picoides dorsalis Baird; hereafter ATWO) woodpeckers prefer to forage on dying trees or recent snags rather than on strongly decayed ones [15-17]. As primary cavity nesters, woodpeckers also rely on snags to excavate cavities for nesting, and they are considered as a keystone species in boreal ecosystems [18]. These breeding cavities initiate successions, as cavities are often used by many secondary cavity nesters/users that are themselves unable to excavate shelters for nesting or roosting [19]. Associations within nest-webs also depend on bird size, where large-bodied primary excavators produce adequate cavities for larger secondary users [20].

Some silvicultural practices, such as partial harvesting [21] or the retention of riverine and remnant linear forests [22,23], maintain deadwood at the landscape scale [24]. However, the artificial supply of snags could also have positive effects on associated wildlife at the stand level [25-27]. In some boreal and temperate ecosystems, is has been shown that tree girdling or leaving high stumps after harvesting generate suitable habitats for saproxylic beetles [27,28], and that tree topping favors the foraging and nesting of primary cavity nesters [29]. It is also possible to enhance the availability of cavities using nest boxes if conservation concerns target secondary cavity nesters [30,31].

However, the spatial distribution of snags at the stand scale may modify the response of the species targeted by mitigation measures. For instance, the concentration of volatiles compounds released by snags (e.g., ethanol, $\alpha$-pinene) should be higher locally in clustered rather than isolated distribution, and be more attractive to ambrosia beetles [32], which, in turn, release aggregative pheromones (e.g., lineatin). This could result in an exponential beetle colonization that could represent an energy-rich food source for predators (e.g., Picidae [13]). Landscape habitat configuration may also influence the effectiveness of local-scale structural enrichment strategies. Indeed, the occupancy of appropriate sites could remain low if the surrounding stands are poor source habitats [33].

The main aim of this study was to determine whether an anthropogenic supply of deadwood attributes (snags by girdling trees and cavities using nest boxes) implemented in a managed boreal forest favor the presence of deadwood-associated species. Based on the detectability of resource pulses, our general hypothesis is that clustered snags should be easier to detect by beetles than snags scattered uniformly throughout a forest stand. A high density of saproxylic beetles would represent an energy-rich food source for predators and could increase the response of woodpeckers [13], but the 
speed and degree of response may differ between the two groups of organisms. We also hypothesized that nest boxes should be used for nesting and roosting by several species.

\section{Methods}

\subsection{Study Area}

This study was conducted about $150 \mathrm{~km}$ northeast of Lac Saint-Jean (Québec, QC, Canada) $\left(49^{\circ} \mathrm{N}\right.$, $71^{\circ} \mathrm{W}$; Figure 1) in 2015 and 2016. This area overlaps two bioclimatic regions, the balsam fir-white birch and the black spruce-feather moss bioclimatic domains. These regions are characterized by coniferous forests dominated mainly by balsam fir (Abies balsamea [L.] Mill.) and black spruce (Picea mariana [Mill.] B.S.P.), accompanied by white spruce (Picea glauca [Moench] Voss), white birch (Betula papyrifera Marsh.), and trembling aspen (Populus tremuloides Michx.) [34]. Spruce budworm outbreaks and wildfires are the main disturbances affecting the balsam fir-white birch and the black spruce-feather moss domains, respectively. The regional topography is undulating, with valleys oriented roughly along a north-south axis. Clearcutting with the protection of regeneration and soils is the most widely practiced harvesting technique in these stands. This method usually cuts all trees $\mathrm{DBH} \geq 9 \mathrm{~cm}$, and leaves small snags $(\mathrm{DBH}<9 \mathrm{~cm})$ in place if they do not represent a security concern for workers.

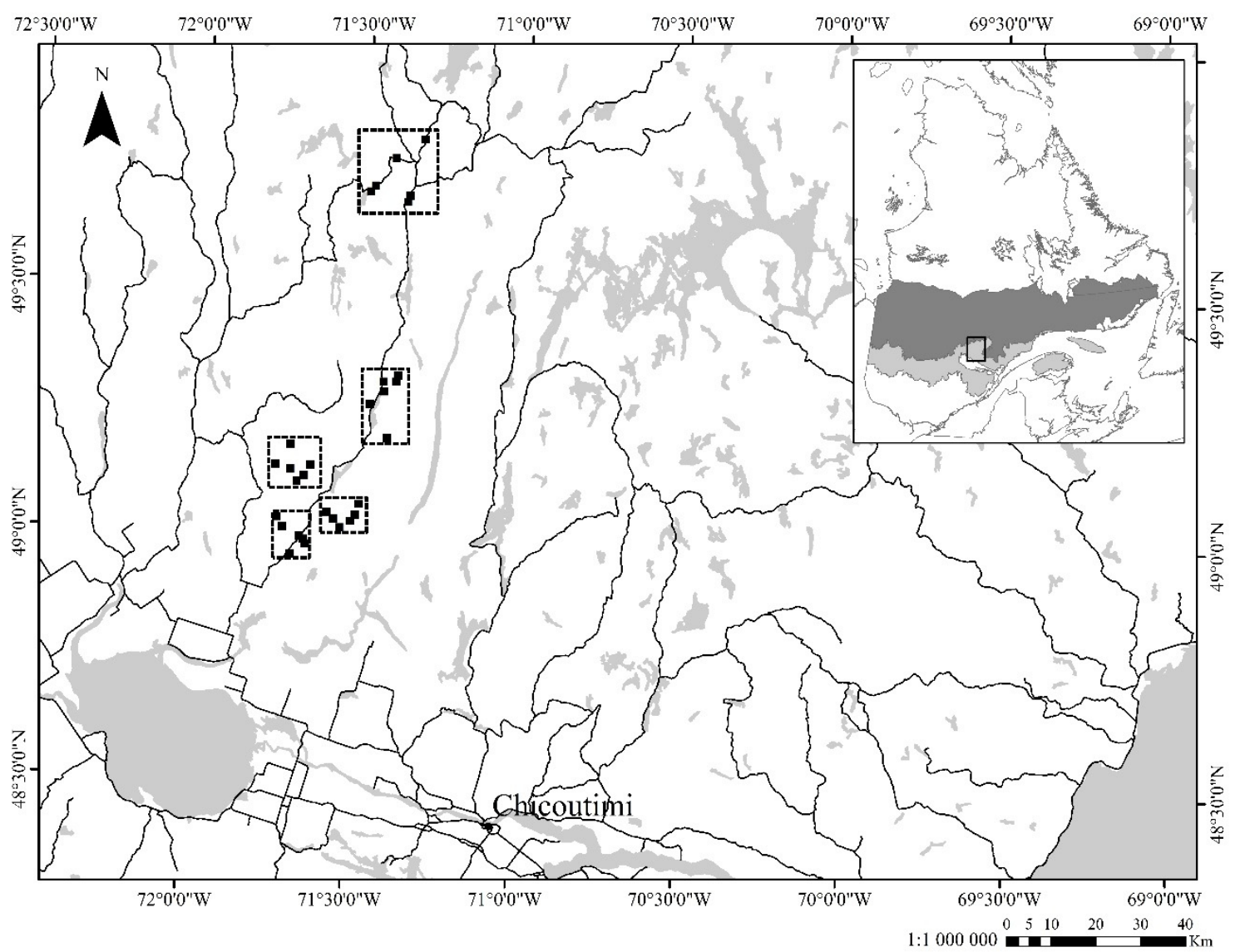

Figure 1. Map of the study area. Black squares represent the experimental sites within the 5 experimental blocks. The inset map shows the balsam fir-white birch (light gray) and the black spruce-feather moss (dark gray) bioclimatic domains. 


\subsection{Experimental Design and Data Collection}

\subsubsection{Experimental Design}

Forest stands were selected using SQL queries on 1:20,000 digital forest maps (Ministère des Forêts de la Faune et des Parcs, Québec, QC, Canada) in ArcGIS 9.3. Selected forest stands ( $\geq 4$ ha) were composed of 50- to 70-year-old black spruces of all height classes and had a canopy closure of $>40 \%$. The selection also included the presence of a forest road (of a width ranging from 3 to $5 \mathrm{~m}$ ) that crossed the stand and excluded any major watercourses or disturbances (e.g., recent fires, insect outbreaks, cut blocks). We conducted a field validation for every site to ensure the forest maps had adequately characterized the actual targeted characteristics.

The study followed a factorial design whereby deadwood supply was increased by girdling trees. Deadwood supply followed two spatial distributions (uniform vs. clustered vs. a no-girdling control), and cavity supply was increased using nest boxes (30/site vs. none). Each treatment was assigned randomly to a 4-ha $(200 \times 200 \mathrm{~m})$ site in five experimental blocks, each block containing six sites $>1.5 \mathrm{~km}$ from one another. Thus, each block had the following treatments: uniform deadwood (DW1), clustered deadwood (DW2), cavities (CV), uniform deadwood with cavities (DW1CV), clustered deadwood with cavities (DW2CV), and control (CT) (Figure 2).

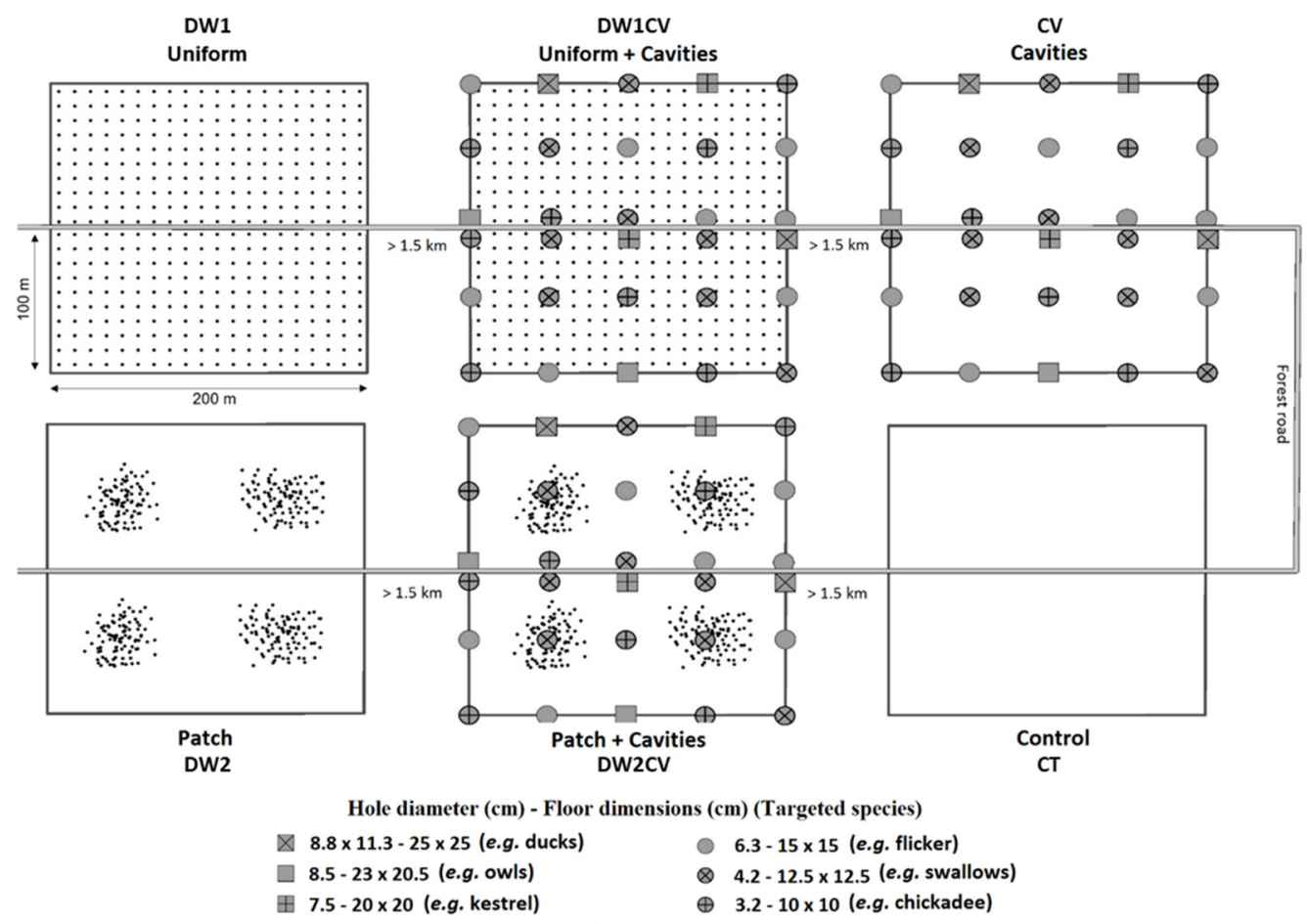

Figure 2. Schematic representation of the 6 experimental sites (i.e., every treatment combination) within each experimental block $(n=5)$. Each black dot represents a girdled tree $(n=400 /$ site). Nest boxes $(n=30 /$ site $)$ are represented by various symbols.

\subsubsection{Deadwood Supply}

Standing deadwood was produced by girdling the trunk at breast height of healthy black spruce $(n=8000)$ in May and June 2015. A total of 400 commercial trees (diameter at breast height or $\mathrm{DBH} \geq 9 \mathrm{~cm}$ ) were girdled in sites where deadwood supply was applied (i.e., 100 trees/ha). This value was a compromise between logistical constraints and the predicted probability of the selection of nesting habitat by BBWO, as documented by Tremblay et al. [35] in similar habitats (probability reaching 50\% in stands with $>200$ recent snags/ha). In DW1 and DW1CV, girdled trees were spaced 
systematically $10 \mathrm{~m}$ from each other, whereas in DW2 and DW2CV, girdled trees were grouped into four clusters centered on points spaced $100 \mathrm{~m}$ from each other (Figure 2).

\subsubsection{Cavity Supply}

To simulate cavities, we installed 30 nest boxes of six different sizes in June 2015 within all CV, DW1CV, and DW2CV sites ( $n=450 ; 7.5$ nest boxes/ha). To assess the edge effect on the use of nest boxes, we placed the three largest nest boxes 0 and $100 \mathrm{~m}$ from the road that crossed each site, whereas we installed the three smaller nest boxes at distances of 0,50 , and $100 \mathrm{~m}$ from the road (Figure 2). Nest box density was determined to test for different combinations of size/distance from the road, but it is also consistent with the density of natural cavities recorded in the balsam fir-white birch bioclimatic domain (11.2/ha [18]). Each nest box was set to be preferably east-facing (except for those along the road) and to avoid exposure from dense lateral cover [35]. Boxes were installed at a height ranging from 2.5 to $4 \mathrm{~m}$.

\subsubsection{Insect Survey}

Saproxylic beetles were sampled using trunk window traps (see [36]) installed on two girdled trees in all DW1, DW2, DW1CV, and DW2CV sites and on two healthy trees in every CT site $(n=50)$. The collecting containers were filled with $70 \%$ ethanol and household vinegar (acetic acid) to preserve specimens. Traps were active for four weeks immediately after girdling (mid-June to mid-July 2015) and one year post-girdling (mid-June to mid-July 2016), which corresponds to the colonization period of most saproxylic species. Ten additional traps were distributed among the CV sites in 2016 to act as a second control for deadwood supply. All samples were processed by the same observer (S. Dufour-Pelletier) and classified into four taxa (Cerambycidae, Curculionidae: Scolytinae (hereafter Scolytinae), other Curculionidae (hereafter Curculionidae), and Cleridae). A second experimented observer (J.-M. Béland) reviewed all samples and identified insects to the lowest possible taxonomic level.

\subsubsection{Foraging Marks Survey}

We surveyed a random subsample of 20 girdled trees in all DW1, DW2, DWCV1, and DWCV2 sites in October $2015(n=400)$ to detect woodpecker foraging marks (i.e., the number of pecking marks or bark scaling surfaces on the first $2 \mathrm{~m}$ above the girdled section). We added another subsample of 20 trees per site for the subsequent sampling periods in June 2016 and October 2016 (total $n=780$, as one site was accidentally harvested during the winter). The same trees were examined over time, and we identified foraging marks with paint at each sampling period to distinguish old and new marks. Because foraging marks observed on the additional subsample trees in June 2016 had not been painted during the first sampling period in October 2015, we used the obvious color differences of sapwood (i.e., dark vs. light brown) between the older and fresh foraging marks-as observed on the trees that had been sampled during the first two periods-as a classification criterion. Foraging marks were not assigned to a specific species of woodpecker.

\subsubsection{Cavity Survey}

We visited every nest box once in mid-June 2016. Those showing signs of use (i.e., vegetation debris, nest, bird presence) were surveyed every week to confirm nesting and to determine productivity and survival rates.

\subsubsection{Vegetation Survey}

We established two circular plots, $11.28 \mathrm{~m}$ radius $\left(400 \mathrm{~m}^{2}\right), 50 \mathrm{~m}$ from the center of each site. Within these plots, we measured the diameter of all trees at breast height $(\mathrm{DBH} \geq 9 \mathrm{~cm})$ using a digital distance measurer (Haglof DME201) and a caliper $( \pm 0.05 \mathrm{~cm})$. Moreover, in October 2016, we classified 
each subsampled girdled tree as living (at least one new twig of the year), dying (no new twigs, a high proportion of red foliage), or dead ( $<20 \%$ foliage remaining). Digital forest maps were used to extract old-growth, perturbed and recently cut forest stands around each site based on a buffer width of $1 \mathrm{~km}$ to avoid overlaps between sites. These variables were included in the foraging mark analyses (see description in Table 1).

Table 1. List and description of habitat variables.

\begin{tabular}{|c|c|}
\hline Code & Habitat Variable \\
\hline \multicolumn{2}{|l|}{ Landscape scale } \\
\hline $\mathrm{RC}$ & $\begin{array}{l}\text { Recent cuts (\% of the buffer zone) } \\
\leq 10 \text {-year-old interventions (excludes thinning) }\end{array}$ \\
\hline MP & $\begin{array}{l}\text { Major natural perturbations ( } \% \text { of the buffer zone) } \\
\text { Severe insect outbreak, burn, windthrow, or deterioration ( } \leq 40 \text { years); affects } \geq 75 \% \text { of the } \\
\text { basal area of the stand }\end{array}$ \\
\hline PP & $\begin{array}{c}\text { Partial natural perturbations ( } \% \text { of the buffer zone) } \\
\text { Partial insect outbreak, burn, windthrow, or deterioration ( } \leq 40 \text { years); affects between } 25 \% \\
\text { and } 75 \% \text { of the basal area of the stand }\end{array}$ \\
\hline OF & $\begin{array}{l}\text { Mature/old-growth stands (\% of the buffer zone) } \\
\geq 90 \text {-year-old even-aged or uneven-aged stands }\end{array}$ \\
\hline ALL & $\mathrm{RC}+\mathrm{MP}+\mathrm{PP}+\mathrm{OF}$ \\
\hline $\begin{array}{l}\text { Site scale } \\
\text { DBH.mean }\end{array}$ & Mean DBH of trees within a site \\
\hline $\begin{array}{l}\text { Tree scale } \\
\text { DBH.Grd } \\
\text { MS.Grd }\end{array}$ & $\begin{array}{l}\text { DBH of a girdled tree } \\
\text { Mortality stage of a girdled tree }\end{array}$ \\
\hline
\end{tabular}

\subsection{Statistical Analysis}

\subsubsection{Saproxylic Beetles}

We first compared the number of captured saproxylic beetles based on deadwood supply treatment and sampling year-including their interaction-using generalized linear mixed models (GLMMs) following a negative binomial error distribution. We ran these analyses separately for each taxon (Cerambycidae, Scolytinae, Curculionidae, and Cleridae). Random effects were the sequential number of traps nested into the interaction of the experimental site and block, and the number of days of capture was used as an offset variable. We used the R-package car to determine the statistical significance of factors and their interaction [37].

\subsubsection{Foraging Marks}

We constructed a set of biologically relevant candidate, mixed-logistic models to predict the probability of the presence of new woodpecker foraging marks on girdled trees, based on deadwood supply treatment, sampling season, mean DBH of trees within vegetation plots, and habitat variables at landscape scale (see Supplementary Table S1). The random effects were the subsampled girdled trees nested into the interaction of experimental site and block. The retained variables in the final model were assessed subsequently using the lowest $\mathrm{AIC}_{\mathrm{c}}$ value. Since the probability of detecting a new foraging mark likely decreases with the intensity at which a tree was used previously, we created a dummy variable that contained the proportion of the tree surface used during the previous sampling period and included this dummy variable in every model.

We used a different mixed logistic model for the 780 subsampled girdled trees surveyed in October 2016 - as we then had information regarding tree degradation stage-to determine the fine-scale variables that best explained the presence of new foraging marks on girdled trees. The fixed effects 
were deadwood supply treatment and the degradation stage of each girdled tree. We used the DBH of girdled trees as a covariate and an interaction term with the deadwood supply treatment. The random structure remained the same as in previous analyses.

All GLMMs were fitted using the R-package lme4 [38], and we used the lsmeans [39] R-package to assess the posteriori comparisons of least-squares means $(\alpha=0.05)$.

\section{Results}

\subsection{Saproxylic Insects}

In 2015, we captured 24,828 saproxylic beetles belonging to 44 species divided among four families/subfamilies compared to 3805 beetles in 2016. In 2015, Cerambycidae, Cleridae, Curculionidae, and Scolytinae accounted for $1.1 \%, 1.0 \%, 1.2 \%$, and $96.7 \%$ of all captured beetles, respectively, compared with $1.4 \%, 2.4 \%, 1.6 \%$, and $94.6 \%$ in 2016. In both years, Trypodendron lineatum (Oliver) was the most abundant species in the traps, representing $88.5 \%(n=21,983)$ of all individuals in 2015 and $74.6 \%(n=2839)$ in 2016 (see Supplementary Table S2).

Overall, we captured significantly more beetles per day in the uniform and clustered sites than in the control sites for all four insect (sub)families (Table 2; this pattern was more pronounced in 2015 than 2016 (Figure 3), and, based on pairwise comparison on the same treatment, it was true for most beetle taxa. We observed no significant difference in the number of beetles captured per day between the uniform and clustered deadwood treatments, except for the Scolytinae in 2016. The interaction between the deadwood supply treatment and year was significant only for the Curculionidae (Table 2).

Table 2. Fixed effects and interaction terms of deadwood supply treatment and sampling year on the daily capture of saproxylic beetles, based on Type III Wald $\chi^{2}$ tests.

\begin{tabular}{ccccc}
\hline \multirow{2}{c}{ Insect (Sub)Families } & $d f$ & Wald Chi-Square & $p$-Value \\
\hline \multirow{3}{*}{ Curculionidae } & Treatment & 2 & 8.08 & 0.018 \\
& Year & 1 & 39.73 & $<0.001$ \\
& Treatment: Year & 2 & 7.19 & 0.027 \\
\hline \multirow{3}{*}{ Cerambycidae } & Treatment & 2 & 20.86 & $<0.001$ \\
& Year & 1 & 18.33 & $<0.001$ \\
& Treatment: Year & 2 & 1.89 & 0.387 \\
\hline \multirow{3}{*}{ Clearidae } & Treatment & 2 & 13.48 & 0.001 \\
& Year & 1 & 15.99 & $<0.001$ \\
& Treatment: Year & 2 & 4.99 & 0.083 \\
\hline \multirow{2}{*}{ Scolytinae } & Treatment & 2 & 14.91 & $<0.001$ \\
& Year & 1 & 48.23 & $<0.001$ \\
& Treatment: Year & 2 & 3.61 & 0.165 \\
\hline
\end{tabular}



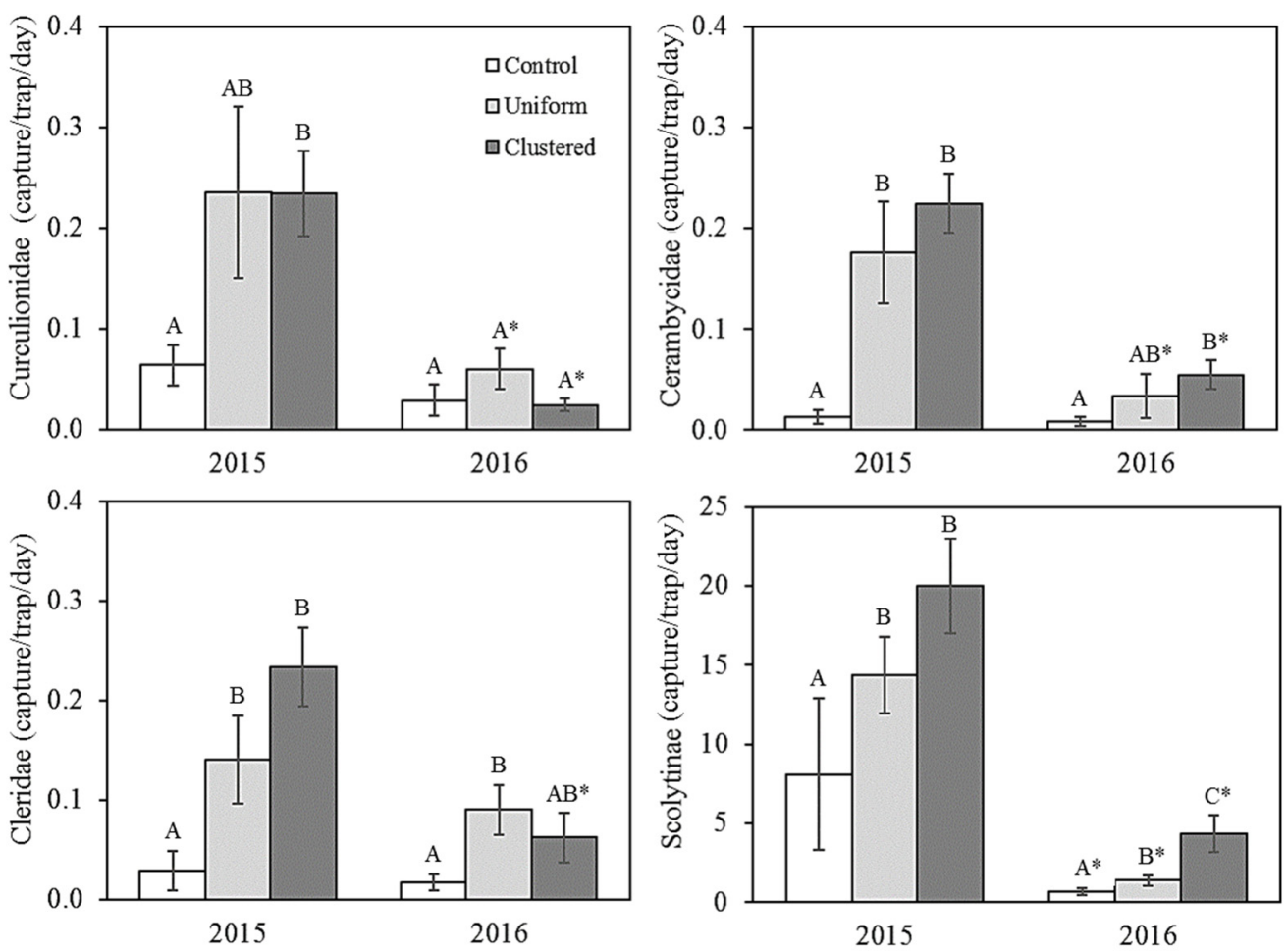

Figure 3. Mean capture $( \pm \mathrm{SE})$ of Curculionidae, Cerambycidae, Cleridae, and Scolytinae per trap/day according to treatment and year. Different letters within a year indicate significantly different least-squares means among treatments, whereas asterisks represent significantly different least-squares means between years for the same treatment $(\alpha=0.05)$.

\subsection{Foraging Marks}

Overall, 17 months after girdling, foraging woodpeckers had used 62.9\% ( $n=490)$ of the subsampled trees $(71.3 \%(n=285)$ in clustered treatments and $54.1 \%(n=205)$ in uniform treatments). According to the best model that included landscape variables and seasons, treatments $\left(\chi^{2}=10.27\right.$, $p=0.001)$ and seasons $\left(\chi^{2}=128.49, p<0.001\right)$ affected the probability of new woodpecker foraging marks with a marginally significant interaction between these main effects $\left(\chi^{2}=5.35, p=0.069\right)$. This probability of presence was similar between the October 2015 and June 2016 samples, but was significantly higher in October 2016 than in October 2015 and June 2016 (Figure 4). For each season, clustered treatments had a significantly higher probability of the presence of foraging marks than uniform treatments. The proportion of recent cuts within a $1 \mathrm{~km}$ buffer around sites also positively affected the probability of use of girdled trees $\left(\chi^{2}=17.08, p<0.001\right)$, although this differed depending on sampling season $\left(\chi^{2}=23.84, p<0.001\right)$. For the uniformly distributed deadwood treatments, a high proportion of recent cuts, $1 \mathrm{~km}$ around sites, tended to increase the probability of use by woodpeckers, although this was more important in October 2015 and June 2016 than in October 2016 (Figure 5a). For clustered deadwood treatments, the same pattern occurred, but with higher probabilities observed for all seasons (Figure $5 b$ ). 


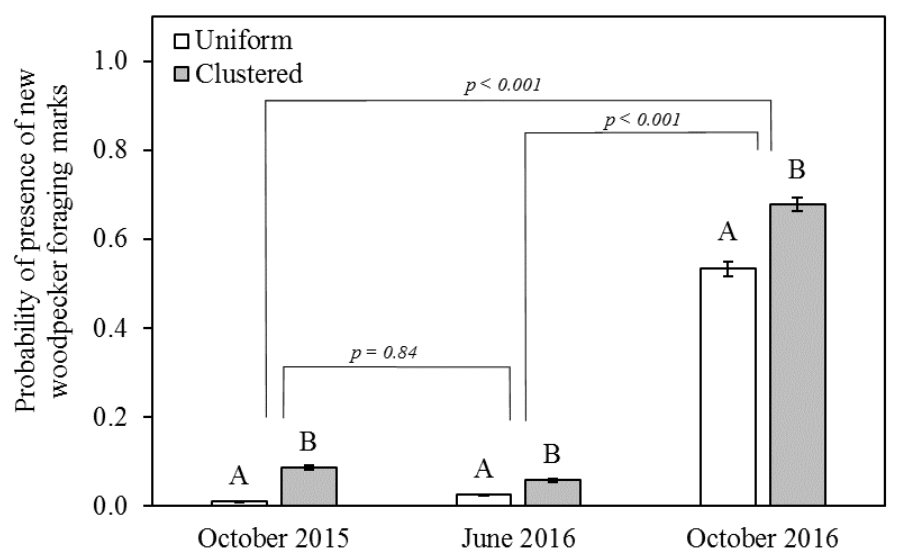

Figure 4. Predicted probability ( \pm SE; back-transformed from the logit scale) of the presence of new woodpecker foraging marks on girdled trees during the three sampling seasons. Different letters within a sampling season indicate significantly different least-squares means among treatments. Lines with an associated $p$-value represent different least-squares means between sampling seasons, regardless of treatment.
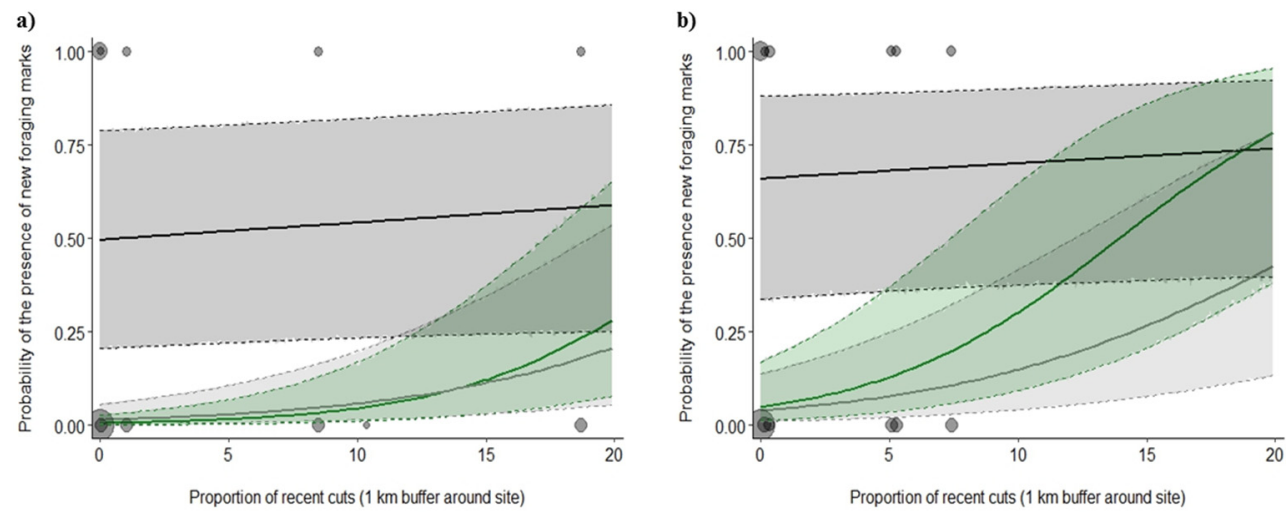

Figure 5. Projected probability of presence of new woodpecker foraging marks $( \pm 95 \% \mathrm{CI})$ on girdled trees sampled in October 2015 (green lines), June 2016 (gray lines), and October 2016 (black lines) based on the proportion of recent cuts $1 \mathrm{~km}$ around sites for (a) uniform and (b) clustered treatments. Gray dots represent the distribution of raw data; the size of the dots is related to the number of observations; darker gray dots are superimposed data.

Of the 780 girdled trees subsampled in October $2016,74.1 \%$ were dead, $9.5 \%$ were dying, $13.1 \%$ were still alive, and 3.3\% were lost (identification tag was not found or had fallen). Treatment, as well as the DBH and the mortality stage of girdled trees, affected the probability of new woodpecker foraging marks $\left(\chi^{2}=4.72, p=0.029 ; \chi^{2}=9.18, p=0.002 ; \chi^{2}=72.23, p<0.001\right.$, respectively). The positive effect of $\mathrm{DBH}$, however, varied depending on treatment $\left(\chi^{2}=4.03, p=0.045\right)$. Indeed, the $\mathrm{DBH}$ of girdled trees had a greater effect on the probability of the presence of new woodpecker foraging marks in uniform treatments (Figure 6a) than in clustered treatments (Figure 6b). 
a)

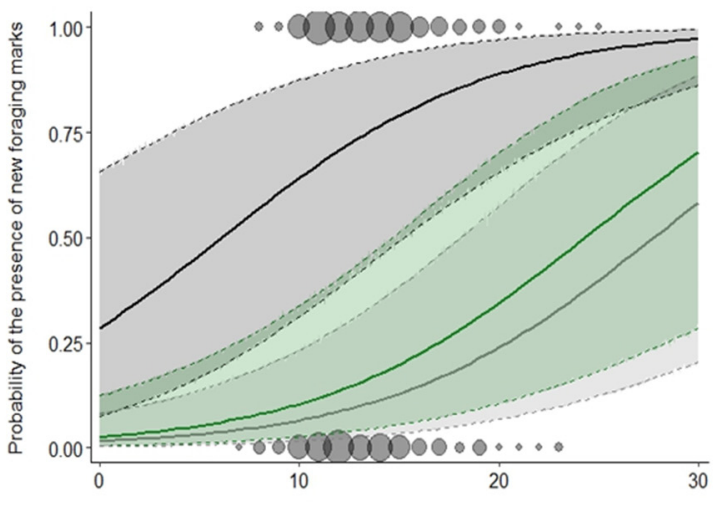

$\mathrm{DBH}$ b)

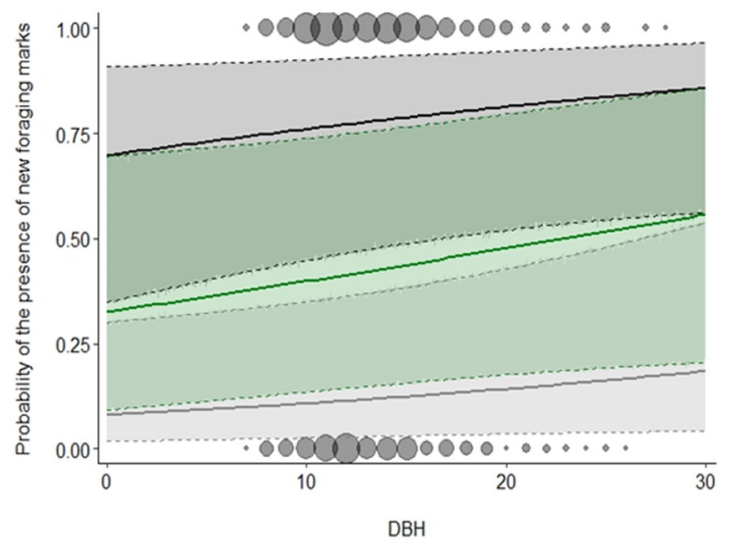

Figure 6. Projected probability of the presence of new woodpecker foraging marks $( \pm 95 \% \mathrm{CI})$ on girdled trees sampled in October 2016, based on the DBH of dead (black lines), dying (green lines), and live trees (gray lines) for (a) uniform and (b) clustered treatments. Gray dots represent the distribution of raw data; the size of dots is related to the number of observations; darker gray dots are superimposed data.

\subsection{Cavity Survey}

Of the 450 nest boxes installed in 2015, only five were used for nesting in June 2016, and all five were used by the Boreal Chickadee (Poecile hudsonicus Forster). These birds occupied the two smaller nest boxes types, and no boxes were located at the edge of the road. All pairs successfully produced 3-5 nestlings.

During the nest box survey of June 2016, we noted that 19 nest boxes (the three smallest sizes) were filled with vegetation debris, probably associated with the activity of squirrels. We also observed that $20.9 \%$ of nest box entrances $(n=94)$ were chewed by squirrels, often in order to enlarge the entrance $(16.7 \%$ of the three largest sizes $(n=15)$ and $21.9 \%$ of the three smallest sizes $(n=79))$.

\section{Discussion}

Our study shows that tree girdling is an effective method for rapidly attracting saproxylic beetles into 50- to 70-year-old, even-aged, black spruce forest stands. For every insect (sub)family sampled, except for Curculionidae (other than Scolytinae), there was a higher number of beetles captured at treatment sites than at control sites. We captured approximately 7 -fold fewer beetles in 2016 (one year after girdling) than in 2015 (a few weeks after girdling); however, the (sub)family composition remained almost the same between years. We also demonstrated that enhancing the snag supply can attract foraging woodpeckers, which, in our study, exclusively used the scaling technique. We observed very few foraging marks in October 2015 (6 months after girdling) and June 2016 (1 year after girdling); in contrast, we found a large number of foraging marks in October 2016 (18 months after girdling). Contrary to what we expected, the sample period with the most foraging marks did not correspond to the period of maximum saproxylic beetle captures. This could be partly or concurrently explained by two factors: (1) beetle captures did not reflect the real colonization rate of girdled trees, and (2) woodpeckers could have failed to detect beetles in 2015, even if there had been beetle colonization.

\subsection{Differences between Snag-Supply Treatments}

Except for Scolytinae in 2016, we did not find any significant difference between uniformly distributed and clustered snags in the number of captured saproxylic beetles. This result partly contrasts with our expectations, since a greater density of recent deadwood would normally increase the concentration of volatiles, and thus favor the detection of suitable habitat patches by saproxylic beetles $[32,40,41]$. Based on the size of experimental sites ( 4 ha) and the relatively low distances between 
girdled trees in the uniformly distributed snag treatments $(10 \mathrm{~m})$, it is possible that the difference in the concentration of volatiles released from snags at the stand scale was not enough to induce a change in their detectability by saproxylic beetles (other than Scolytinae). Saint-Germain, Buddle and Drapeau [32] reported that, even if beetles in flight orient themselves toward habitat patches using host volatiles, they randomly land on trees and then perform a final host selection in a trial-and-error manner. However, although not statistically significant, we did observe a general trend of greater captures of some beetle (sub)families other than Scolytinae in the clustered treatments.

Unlike saproxylic insects, woodpeckers foraged more on girdled trees in the clustered treatments than uniform treatments. Foraging decisions may be based on information gathered across multiple spatiotemporal scales, as demonstrated for the Magellanic Woodpecker (Campephilus magellanicus King [42]). Indeed, this species acts as a locally informed forager and uses visual clues from the immediate vicinity to select individual trees, whereas the time spent to forage on the same tree is rather influenced by their long-time memory of tree availability along the foraging route or within their home range and tree-level attributes (e.g., DBH, decay stage). Based on these foraging strategies, woodpeckers in our study area could have been more likely to locate girdled trees in clustered treatments compared with uniform treatments, as foraging sites (i.e., girdled trees) were closer to one another. Woodpeckers would have used them intensively, given that the foraging substrate was more abundant and prey was more concentrated in these treatments than in those along their foraging route.

\subsection{Effect of Spatial Scale on Snag Use}

The presence of woodpecker foraging marks was positively associated with the proportion of recent cuts ( $\leq 10$ years) at $1 \mathrm{~km}$ around sites. These results are similar to those obtained in other sites, where BBWO often nest in residual snags in recent cuts [35,43]. It has also been shown that ATWO use clear-cut edges as movement corridors [44]. The more open habitats around our experimental sites may have favored movement between the fine-scale habitat components within the woodpeckers' home range (e.g., open nesting habitats toward denser foraging habitats) and increased the probability of detecting girdled trees. This explanation is more plausible for fall 2015 and spring 2016, when girdled trees were likely less suitable or less attractive for woodpeckers, than in fall 2016, where the high attractiveness of the snag supply treatments was the principal driver of the foraging habitat selection of woodpeckers.

At a finer scale, the probability of the presence of new woodpecker foraging marks in October 2016 was associated with larger-sized, recently dead trees. These results are consistent with the recorded foraging behavior of boreal woodpeckers (e.g., [15,16,44,45]). Indeed, larger trees are more likely to harbor a higher density and diversity of saproxylic beetles [46,47]. However, the size of girdled trees was less important in clustered snag treatments, as woodpeckers were more likely to forage on closer suitable trees, rather than search systematically for larger ones. In forest sites near to our study area, foraging ATWO and BBWO selected trees having a mean DBH $\pm S E$ of $19.2 \pm 0.5 \mathrm{~cm}$ and $18.3 \pm 0.4 \mathrm{~cm}$, respectively $[15,45]$. Given a mean DBH of $13.5 \pm 0.1 \mathrm{~cm}$ for the 780 subsampled girdled trees, we can assume that girdling larger trees would be more suitable for foraging woodpeckers. A substantial proportion of girdled trees $(13.6 \%)$ remained alive even 1.5 years post-girdling. It has been shown that girdled trees can live and even continue to grow for 1-2 years after girdling before their roots die from a lack of photosynthate [48].

\subsection{Time Lag between Beetle Capture and Woodpecker Foraging-Mark Abundance}

Trunk window traps assess visitation rates at trees, but substantial differences may exist with colonization rates $[49,50]$. Indeed, even if the number of beetles caught in traps was much greater in 2015 than in 2016, a weak insect colonization success may have occurred in 2015 and could have led to a low food supply for woodpeckers. This could explain the few foraging marks that were observed in fall 2015 and spring 2016. 
The striped-ambrosia beetle, T. lineatum, was by far the most abundant species captured in both 2015 and 2016. This wood-boring ambrosia beetle is highly attracted by ethanol produced via the anaerobic metabolism of stressed or dying trees and, to a lesser extent, by low levels of the monoterpene $\alpha$-pinene [51]. After mating, females bore galleries at approximately $2 \mathrm{~cm}$ deep into the sapwood to oviposit. McIntosh and McLean [52] estimated that T. lineatum (adults and their brood) gradually exit their galleries (and the tree) following an accumulation of 265 degree-days above a $13^{\circ} \mathrm{C}$ threshold after gallery establishment; this threshold is reached around mid-July in meridional Canadian temperatures, such as those found in the study area. Even if T. lineatum is highly attracted to recently dead trees, it has been shown that this species prefers colonizing timber killed at the previous fall or winter, rather than trees killed the same spring [53]. These trees will have undergone ethanol production for a longer period of time and are more likely to have lower starch content in the sapwood and lower cell viability. Moreover, conifers have a well-developed constitutive and induced defense system to prevent and counter bark beetle attacks $[48,54,55]$. It therefore may be plausible that the colonization of the stressed living girdled trees in 2015 did not occur proportionally to the number of beetles visiting girdled trees, as reflected by the number on insects captured in trunk window traps. However, our field observations confirm a certain degree of colonization, since frass (i.e., boring dust and feces cleaned out from galleries) had accumulated on the bark scales and at the base of several tree boles. Inversely, in 2016, the more advanced degradation of girdled trees may have weakened the defense mechanisms of these trees and favored adequate sapwood characteristics, thereby allowing a marked colonization of saproxylic beetles and producing suitable foraging substrates for woodpeckers.

The asynchrony between woodpecker foraging activities and beetle captures in traps could also have resulted from a failure of woodpeckers to detect beetle abundance in 2015. In our study area, BBWO and ATWO are the two main species likely to forage via bark scaling [17]. Both species forage almost exclusively on dying or recently dead conifers [16,56,57]. In black spruce forests, Cadieux and Drapeau [17] showed that bark scaling frequency by Picoides was significantly higher in $>90$-year-old unpaludified stands than in 60- to 90-year-old stands, mainly because the former stands have a higher density of recently dead trees. Given that very few girdled trees showed visual signs of degradation during the first summer (i.e., red foliage) and the young age of forest stands (i.e., similar to the younger stands studied by Cadieux and Drapeau [17]), the woodpeckers may not have been attracted to girdled trees in fall 2015 and spring 2016 as the habitat still looked unsuitable (see [58]). This is also consistent with our observations in October 2016, that most foraging marks were on recently dead girdled trees, even though living and dying girdled trees remained available.

\subsection{Other Time-Related Effects on the Response of Insects and Birds to Snag Supply}

The absence of woodpecker excavation marks into the wood during our survey suggests that they only fed on beetles present within or directly underneath the bark (i.e., mostly adult Scolytinae). Most frequently, BBWO excavate small holes to find wood-boring beetles, but may also rely on the scaling technique to access bark beetles [15]. ATWO always prefer to feed on bark beetles [16,57]. Assuming a marked insect colonization only in spring 2016, and given that T. lineatum (adults and broods) remained in the sapwood of girdled trees until at least mid-July, it is more likely that the high proportion of new foraging marks detected in October 2016 was due to a high emergence rate of beetles during the late summer [59]. This higher foraging activity may also have been exacerbated by the persistence of adult beetles on girdled trees for overwintering combined with the fall dispersion of juvenile woodpeckers (Tremblay et al. [60], unpublished data). Such a pulse in resource availability could have increased the cost-benefit ratio associated with foraging activities.

Moreover, the low abundance of new foraging marks on girdled trees in spring 2016, which covers the time frame between October 2015 and June 2016, could also be explained by a different foraging ecology of woodpeckers during the breeding season. Indeed, it has been demonstrated that, during this period, Scolytinae were rare in the BBWO diet and nestlings were provisioned with Cerambycidae 
(Tremblay et al. [60], unpublished data). One may suppose that Scolytinae are not as energetically valuable as other prey available during the breeding season (sensu [61]).

\subsection{Effect of Cavity Supply}

Only five Boreal Chickadee pairs used nest boxes (1.1\% of available boxes) and occupied the two smaller box sizes located away from the forest edge. The selection of small-sized nest boxes by chickadees over larger boxes has also been observed in a nest-site limitation experiment in western Canadian boreal forests [30].

Nest box occupancy in this study was lower than in some other cavity-supply studies in different forest systems [62-64]. However, other studies noted that nest box occupancy tends to increase with time following installation $[63,65,66]$, suggesting that we might expect a greater use of our installed nest boxes in the upcoming years. In fact, nest box reuse among birds is common, and this is especially true after a successful nesting, although this reuse varies widely between species [67,68].

The use of nest boxes as roosting sites by red squirrels (Tamiasciurus hudsonicus Erxleben) and northern flying squirrels (Glaucomys sabrinus Shaw) is also common [69,70]. However, given their ability to construct bolus nests in the tree canopy and use underground burrows [71], squirrels are likely not limited by cavity availability [72]. On the other hand, Aitken and Martin [30] hypothesized that squirrels' preference for large-sized boxes and the enlargement of the entrances of smaller boxes may indicate a shortage of suitable large-sized den sites in their study area. This statement does not seem to apply to our study, as only the three smaller sizes of boxes were used for roosting, and larger nest boxes were chewed almost as much as the smaller ones.

\section{Conclusions}

With the implementation of ecosystem-based management, forest managers should aim to limit the simplification of the internal structure of forest stands and the loss of certain types of deadwood [73]. To achieve that, researchers highlighted the importance of leaving a greater variety of post-harvest forest remnants in terms of width, composition and structural attributes [3,24]. Similarly, in black spruce forests, Tremblay, Savard and Ibarzabal [35] recommended the protection of 50-ha patches of old irregular forest stands embedded in at least 30\% of remnant productive forests within agglomeration of cut blocks. The use of extensive silvicultural treatments, such as partial cutting, may also provide a suitable habitat over the long-term for deadwood-associated species [16,35]. Nevertheless, when forest structures have been locally driven beyond their natural range of variability and a conservation concern is identified, structural enrichment may serve as an effective compensatory measure to palliate such deficits. If a problem occurs at a larger scale, tree girdling to increase snag supply could be integrated into actual forest practices (e.g., at the time of thinning, see [27]). As these strategies can quickly become expensive, they may be applied in specific situations, for instance ecological restoration [74], where managers should prioritize their actions based on the greatest potential for ecological benefits. We have shown that anthropogenic treatments aiming to attract early successional saproxylic beetles and foraging boreal woodpeckers should be done by girdling black spruce in several clusters and choose the largest trees available. These snags would remain suitable for these species over the first few years and would then become suitable for many other species during the process of decay (e.g., primary and secondary cavity users, late-successional saproxylic organisms). However, too many snags at a local scale could actually reduce the occupancy of individual snags, as the availability of the resource would surpass the capacity of beetle communities to colonize these habitats (Ibarzabal et al., Unpublished data). Further studies in eastern Canadian boreal forests should aim to test different structural enrichment strategies (e.g., killing methods, target species, optimal quantities) according to different levels of management intensity. More adaptive methods could thus facilitate their implementation in commercial activities and favor ecological benefits at larger scales. 
Supplementary Materials: The following are available online at http://www.mdpi.com/1999-4907/11/4/424/s1, Table S1: Set of biologically relevant candidate models to predict the probability of presence of new foraging marks on girdled trees. The information includes the number of parameters in the model (K), the log-likelihood (LL), the AIC corrected for small samples (AICc), the relative difference in AICc value compared to the top-ranked model $(\triangle \mathrm{AICc})$, and the Akaike weight (wi); Table S2: List of captured saproxylic beetles.

Author Contributions: Conceptualization: S.D.-P., J.A.T. and J.I.; Methodology: S.D.-P., J.A.T. and J.I.; Field Work: S.D.-P.; Formal Analysis: S.D.-P.; Resources: C.H. and T.L.; Writing-Original Draft Preparation: S.D.-P.; Writing-Review and Editing: J.A.T., J.I., C.H. and T.L.; Supervision: J.A.T. and J.I.; Project Administration: J.I.; Funding Acquisition: J.I. and S.D.-P. All authors have read and agreed to the published version of the manuscript.

Funding: This research was funded by the Programme de Financement de la Recherche et Développement en Aménagement Forestier of the Ministère des Ressources Naturelles du Québec, Hydro-Québec, theet le Ministère des Forêts, de la Faune et des Parcs. Financial contributions to Samuel Dufour-Pelletier were obtained from Bird protection Quebec, the Bern University of Applied Sciences, and Environment and Climate Change Canada.

Acknowledgments: We thank J. Tremblay, J. Lavoie, J.-G. Girard, M.-J. Tremblay, T. Tremblay, K. Bergeron, C. Lemieux, M. St-Gelais, É. Dussault-Chouinard, P. Pettigrew, and V. Fortin-Castonguay for their help during fieldwork. We also thank J.-M. Béland, from Natural Resources Canada-Canadian Forest Service, who identified insects.

Conflicts of Interest: The authors declare no conflict of interest.

\section{References}

1. Cyr, D.; Gauthier, S.; Bergeron, Y.; Carcaillet, C. Forest management is driving the eastern North American boreal forest outside its natural range of variability. Front. Ecol. Environ. 2009, 7, 519-524. [CrossRef]

2. Boucher, D.; De Grandpré, L.; Kneeshaw, D.; St-Onge, B.; Ruel, J.-C.; Waldron, K.; Lussier, J.-M. Effects of 80 years of forest management on landscape structure and pattern in the eastern Canadian boreal forest. Landsc. Ecol. 2015, 30, 1913-1929. [CrossRef]

3. Vaillancourt, M.A.; Drapeau, P.; Gauthier, S.; Robert, M. Availability of standing trees for large cavity-nesting birds in the eastern boreal forest of Québec, Canada. For. Ecol. Manag. 2008, 255, 2272-2285. [CrossRef]

4. Drapeau, P.; Nappi, A.; Imbeau, L.; Saint-Germain, M. Standing deadwood for keystone bird species in the eastern boreal forest: Managing for snag dynamics. For. Chron. 2009, 85, 227-234. [CrossRef]

5. Imbeau, L.; St-Laurent, M.H.; Marzell, L.; Brodeur, V. Current capacity to conduct ecologically sustainable forest management in northeastern canada reveals challenges for conservation of biodiversity. Can. J. For. Res. 2015, 45, 567-578. [CrossRef]

6. Nappi, A.; Drapeau, P.; Savard, J.-P.L. Salvage logging after wildfire in the boreal forest: Is it becoming a hot issue for wildlife? For. Chron. 2004, 80, 67-74. [CrossRef]

7. Siitonen, J. Threatened saproxylic species. In Biodiversity in Deadwood; Stokland, J.N., Siitonen, J., Jonsson, B.G., Eds.; Cambridge University Press: Cambridge, UK, 2012; pp. 356-379.

8. Imbeau, L.; Mönkkönen, M.; Desrochers, A. Long-term effects of forestry on birds of the eastern canadian boreal forests: A comparison with fennoscandia. Conserv. Biol. 2001, 15, 1151-1162. [CrossRef]

9. Gauthier, S.; Vaillancourt, M.A.; Leduc, A.; De Grandpré, L.; Kneeshaw, D.; Morin, H.; Drapeau, P.; Bergeron, Y. Ecosystem Management in the Boreal Forest; Presses de l'Université du Québec: Québec, QC, Canada, 2009.

10. Boucher, Y.; Perrault-Hébert, M.; Fournier, R.; Drapeau, P.; Auger, I. Cumulative patterns of logging and fire (1940-2009): Consequences on the structure of the eastern Canadian boreal forest. Landsc. Ecol. 2016, 2, 361-375. [CrossRef]

11. Siitonen, J. Forest management, coase woody debris and saproxylic organisms: Fennoscandian boreal forests as an example. Ecol. Bull. 2001, 49,11-41.

12. Stokland, J.N.; Siitonen, J.; Jonsson, B.G. Biodiversity in Dead Wood; Cambridge University Press: Cambridge, UK, 2012; p. 509.

13. Edworthy, A.B.; Drever, M.C.; Martin, K. Woodpeckers increase in abundance but maintain fecundity in response to an outbreak of mountain pine bark beetles. For. Ecol. Manag. 2011, 261, 203-210. [CrossRef]

14. Nappi, A.; Drapeau, P.; Saint-Germain, M.; Angers, V.A. Effect of fire severity on long-term occupancy of burned boreal conifer forests by saproxylic insects and wood-foraging birds. Int. J. Wildland Fire 2010, 19, 500-511. [CrossRef]

15. Tremblay, J.A.; Ibarzabal, J.; Savard, J.-P.L. Foraging ecology of black-backed woodpeckers (Picoides arcticus) in unburned eastern boreal forest stands. Can. J. For. Res. 2010, 40, 991-999. [CrossRef] 
16. Nappi, A.; Drapeau, P.; Leduc, A. How important is dead wood for woodpeckers foraging in eastern North American boreal forests? For. Ecol. Manag. 2015, 346, 10-21. [CrossRef]

17. Cadieux, P.; Drapeau, P. Are old boreal forests a safe bet for the conservation of the avifauna associated with decayed wood in eastern Canada? For. Ecol. Manag. 2017, 385, 127-139. [CrossRef]

18. Ouellet-Lapointe, U.; Drapeau, P.; Cadieux, P.; Imbeau, L. Woodpecker excavations suitability for and occupancy by cavity users in the boreal mixedwood forest of eastern Canada. Ecoscience 2015, 19, 391-397. [CrossRef]

19. Aitken, K.E.H.; Martin, K. The importance of excavators in hole-nesting communities: Availability and use of natural tree holes in old mixed forests of western Canada. J. Ornithol. 2007, 148, 425-434. [CrossRef]

20. Martin, K.; Aitken, K.E.H.; Wiebe, K.L. Nest sites and nest webs for cavity-nesting communities in interior British Columbia, Canada: Nest characteristics and niche partitioning. Condor 2004, 106, 5-19. [CrossRef]

21. Santaniello, F.; Djupstrom, L.B.; Ranius, T.; Weslien, J.; Rudolphi, J.; Sonesson, J. Simulated long-term effects of varying tree retention on wood production, dead wood and carbon stock changes. J. Environ. Manag. 2017, 201, 37-44. [CrossRef]

22. Remm, J.; Lõhmus, A.; Remm, K. Tree cavities in riverine forests: What determines their occurrence and use by hole-nesting passerines? For. Ecol. Manag. 2006, 221, 267-277. [CrossRef]

23. Vaillancourt, M.-A. Effets des régimes de perturbation par le chablis sur la biodiversité et les implications pour la récupération: Revue de littérature. In Direction du Développement Socio-Économique des Partenariats et de L'éducation; Ministère des Ressources Naturelles et de la Faune: Québec, QC, Canada, 2008.

24. Moussaoui, L.; Fenton, N.J.; Leduc, A.; Bergeron, Y. Can retention harvest maintain natural structural complexity? A comparison of post-harvest and post-fire residual patches in boreal forest. Forests 2016, 7, 243. [CrossRef]

25. Hane, M.E.; Kroll, A.J.; Johnson, J.R.; Rochelle, M.; Arnett, E.B. Experimental effects of structural enrichment on avian nest survival. For. Ecol. Manag. 2012, 282, 167-174. [CrossRef]

26. Seibold, S.; Bässler, C.; Brandl, R.; Gossner, M.M.; Thorn, S.; Ulyshen, M.D.; Müller, J. Experimental studies of dead-wood biodiversity-A review identifying global gaps in knowledge. Biol. Conserv. 2015, 191, 139-149. [CrossRef]

27. Thibault, M.; Moreau, G. Enhancing bark- and wood-boring beetle colonization and survival in vertical deadwood during thinning entries. J. Insect Conserv. 2016, 20, 789-796. [CrossRef]

28. Ranius, T.; Caruso, A.; Jonsell, M.; Juutinen, A.; Thor, G.; Rudolphi, J. Dead wood creation to compensate for habitat loss from intensive forestry. Biol. Conserv. 2014, 169, 277-284. [CrossRef]

29. Barry, A.M.; Hagar, J.C.; Rivers, J.W. Long-term dynamics and characteristics of snags created for wildlife habitat. For. Ecol. Manag. 2017, 403, 145-151. [CrossRef]

30. Aitken, K.E.H.; Martin, K. Experimental test of nest-site limitation in mature mixed forests of central British Columbia, Canada. J. Wildlife Manag. 2012, 76, 557-565. [CrossRef]

31. Newton, I. The role of nest sites in limiting the numbers of hole-nesting birds: A review. Biol. Conserv. 1994, 70, 265-276. [CrossRef]

32. Saint-Germain, M.; Buddle, C.M.; Drapeau, P. Sampling saproxylic coleoptera: Scale issues and the importance of behavior. Environ. Entomol. 2006, 35, 478-487. [CrossRef]

33. Kroll, A.J.; Duke, S.D.; Hane, M.E.; Johnson, J.R.; Rochelle, M.; Betts, M.G.; Arnett, E.B. Landscape composition influences avian colonization of experimentally created snags. Biol. Conserv. 2012, 152, 145-151. [CrossRef]

34. Saucier, J.P.; Grondin, P.; Robitaille, A.; Gosselin, J.; Morneau, C.; Richard, J.H.; Brisson, J.; Sirois, L.; Leduc, A.; Morin, H.; et al. Écologie forestière. In Manuel de Foresterie; Éditions Multi-Mondes: Montréal, QC, Canada, 2009; pp. 133-279.

35. Tremblay, J.A.; Savard, J.-P.L.; Ibarzabal, J. Structural retention requirements for a key ecosystem engineer in conifer-dominated stands of a boreal managed landscape in eastern Canada. For. Ecol. Manag. 2015, 357, 220-227. [CrossRef]

36. Kaila, L. A new method for collecting quantitative samples of insects associated with decaying wood or wood fungi. Entomol. Fenn. 1993, 4, 21-23. [CrossRef]

37. John, F.; Sanford, W. An R Companion to Applied Regression; SAGE Inc.: Thousand Oaks, CA, USA, 2011.

38. Bates, D.; Maechler, M.; Bolker, B.; Walker, S. Fitting Linear Mixed-Effects Models Using lme4. J. Stat. Softw. 2015, 67, 1-48. [CrossRef]

39. Lenth, R.V. Least-Squares Means: The R Package lsmeans. J. Stat. Softw. 2016, 69, 1-33. [CrossRef] 
40. Lindelöw, Å.; Risberg, B.; Sjödin, K. Attraction during flight of scolytids and other bark-and wood-dwelling beetles to volatiles from fresh and stored spruce wood. Can. J. For. Res. 1992, 22, 224-228. [CrossRef]

41. Park, J.; Reid, M.L. Distribution of a bark beetle, Trypodendron lineatum, in a harvested landscape. For. Ecol. Manag. 2007, 242, 236-242. [CrossRef]

42. Vergara, P.M.; Soto, G.E.; Moreira-Arce, D.; Rodewald, A.D.; Meneses, L.O.; Pérez-Hernández, C.G. Foraging behaviour in magellanic woodpeckers is consistent with a multi-scale assessment of tree quality. PLoS ONE 2016, 11, e0159096. [CrossRef]

43. Craig, C.; Mazerolle, M.J.; Taylor, P.D.; Tremblay, J.A.; Villard, M.-A. Predictors of habitat use and nesting success for two sympatric species of boreal woodpeckers in an unburned, managed forest landscape. For. Ecol. Manag. 2019, 438, 134-141. [CrossRef]

44. Gagné, C.; Imbeau, L.; Drapeau, P. Anthropogenic edges: Their influence on the American three-toed woodpecker (Picoides dorsalis) foraging behaviour in managed boreal forests of Quebec. For. Ecol. Manag. 2007, 252, 191-200. [CrossRef]

45. Imbeau, L.; Desrochers, A. Foraging ecology and use of drumming trees by three-toed woodpeckers. J. Wildlife Manag. 2002, 66, 222-231. [CrossRef]

46. Azeria, E.T.; Ibarzabal, J.; Hebert, C. Effects of habitat characteristics and interspecific interactions on co-occurrence patterns of saproxylic beetles breeding in tree boles after forest fire: Null model analyses. Oecologia 2012, 168, 1123-1135. [CrossRef]

47. Saint-Germain, M.; Drapeau, P.; Hébert, C. Xylophagous insect species composition and patterns of substratum use on fire-killed black spruce in central Quebec. Can. J. For. Res. 2004, 34, 677-685. [CrossRef]

48. Franceschi, V.R.; Krokene, P.; Christiansen, E.; Krekling, T. Anatomical and chemical defenses of conifer bark against bark beetles and other pests. New Phytol. 2005, 167, 353-375. [CrossRef] [PubMed]

49. Béland, J.M.; Bauce, É.; Cloutier, C.; Berthiaume, R.; Hébert, C. Early responses of bark and wood boring beetles to an outbreak of the hemlock looper Lambdina fiscellaria (Guenée) (Lepidoptera: Geometridae) in a boreal balsam fir forest of North America. Agric. For. Entomol. 2019, 21, 407-416. [CrossRef]

50. Boucher, J.; Azeria, E.T.; Ibarzabal, J.; Hébert, C. Saproxylic beetles in disturbed boreal forests: Temporal dynamics, habitat associations, and community structure. Ecoscience 2012, 19, 328-343. [CrossRef]

51. Bauer, J.; Vité, J.P. Host selection by Trypodendron lineatum. Die Naturwissenschaften 1975, 62, 539. [CrossRef]

52. McIntosh, R.L.; McLean, J.A. Developmental threshold for the striped ambrosia beetle Trypodendron lineatum: A first estimate. J. Enthomol. Soc. Brit. Columbia 1997, 94, 19-26.

53. Dyer, E.D.A.; Chapman, J.A. Flight and attack of the ambrosia beetle, Trypodendron lineatum (Oliv.) in relation to felling date of logs. Can. Entomol. 1965, 97, 42-57. [CrossRef]

54. Francezon, N.; Stevanovic, T. Chemical Composition of Essential Oil and Hydrosol from Picea mariana Bark Residue. BioRessources 2017, 12, 2635-2645. [CrossRef]

55. Nijholt, W.W. The striped ambrosia beetle. In Forest Service; Natural Ressources Canada: Victoria, BC, Canada, $1979 ;$ p. 35.

56. Tremblay, J.A.; Dixon, R.D.; Saab, V.A.; Pyle, P.; Patten, M.A. Black-backed Woodpecker (Picoides arcticus), version 3.0. In The Birds of North America; Cornell Lab of Ornithology: Ithaca, NY, USA, 2016.

57. Tremblay, J.A.; L., L.J.D.; Imbeau, L. American Three-toed Woodpecker (Picoides dorsalis), version 2.0. In The Birds of North America; Cornell Lab of Ornithology: Ithaca, NY, USA, 2018.

58. Vergara, P.M.; Saura, S.; Pérez-Hernández, C.G.; Soto, G.E. Hierarchical spatial decisions in fragmented landscapes: Modeling the foraging movements of woodpeckers. Ecol. Model. 2015, 300, 114-122. [CrossRef]

59. Dyer, E. Attack and Brood Production of Ambrosia Beetles in Logging Debris. Can. Entomol. 1963, 95, 624-631. [CrossRef]

60. Tremblay, J.A.; Fontaine, G.L.; Ibarzabal, J.; Savard, J.-P.L.; Béland, J.-M.; Hébert, C. Diet composition of two Boreal Woodpeckers (Picoides arcticus and P. dorsalis) in eastern Canada. (unpublished; manuscript in preparation).

61. Rota, C.T.; Rumble, M.A.; Lehman, C.P.; Kesler, D.C.; Millspaugh, J.J. Apparent foraging success reflects habitat quality in an irruptive species, the Black-backed Woodpecker. Condor Ornithol. Appl. 2015, 117, 178-191. [CrossRef]

62. Cockle, K.L.; Martin, K.; Drever, M.C. Supply of tree-holes limits nest density of cavity-nesting birds in primary and logged subtropical Atlantic forest. Biol. Conserv. 2010, 143, 2851-2857. [CrossRef] 
63. Miller, K.E. Nest-site limitation of secondary cavity-nesting birds in even-age southern pine forests. Wilson J. Ornithol. 2010, 122, 126-134. [CrossRef]

64. Robles, H.; Ciudad, C.; Matthysen, E. Responses to experimental reduction and increase of cavities by a secondary cavity-nesting bird community in cavity-rich Pyrenean oak forests. For. Ecol. Manag. 2012, 277, 46-53. [CrossRef]

65. Brawn, J.D.; Balda, R.P. Population biology of cavity nesters in northern Arizona: Do nest sites limit breeding densities? Condor 1988, 90, 61-71. [CrossRef]

66. Cuatianquiz Lima, C.; Macias Garcia, C. Pre- and post-experimental manipulation assessments confirm the increase in number of birds due to the addition of nest boxes. PeerJ 2016, 4, e1806. [CrossRef]

67. Stanback, M.T.; Rockwell, E.K. Nest-Site Fidelity in Eastern Bluebirds (Sialia Sialis) Depends on the Quality of Alternate Cavities. Auk 2003, 120, 1029-1032. [CrossRef]

68. Steenhof, K.; Peterson, B.E. Site fidelity, mate fidelity, and breeding dispersal in American kestrels. Wilson J. Ornithol. 2009, 121, 12-21. [CrossRef]

69. Priol, P.; Mazerolle, M.J.; Imbeau, L.; Drapeau, P.; Trudeau, C.; Ramiere, J. Using dynamic N-mixture models to test cavity limitation on northern flying squirrel demographic parameters using experimental nest box supplementation. Ecol. Evol. 2014, 4, 2165-2177. [CrossRef]

70. Trudeau, C.; Imbeau, L.; Drapeau, P.; Mazerolle, M.J. Winter site occupancy patterns of the northern flying squirrel in boreal mixed-wood forests. Mamm. Biol. Z. Säugetierkd. 2012, 77, 258-263. [CrossRef]

71. Benhamou, S. Space use and foraging movements in the American red squirrel (Tamiasciurus hudsonicus). Behav. Process. 1996, 37, 89-102. [CrossRef]

72. Ransome, D.B.; Sullivan, T.P. Effects of food and den-site supplementation on populations of Glaucomys sabrinus and Tamiasciurus douglasii. J. Mammal. 2004, 85, 206-215. [CrossRef]

73. Jetté, J.-P.; Leblanc, M.; Bouchard, M.; Déry, S.; Villeneuve, N. Intégration des enjeux écologiques dans les plans d'aménagement forestier intégré. Partie I-Analyse des enjeux, version 1.1. In Direction de L'aménagement et de L'environnement Forestiers; Ministère des Ressources Naturelles et de la Faune: Québec, QC, Canada, 2012; p. 159.

74. Versluijs, M.; Roberge, J.-M.; Eggers, S.; Boer, J.; Hjältén, J. Ecological restoration for biodiversity conservation improves habitat quality for an insectivorous passerine in boreal forest. Biol. Conserv. 2019, 237, 90-96. [CrossRef]

(C) 2020 by the authors. Licensee MDPI, Basel, Switzerland. This article is an open access article distributed under the terms and conditions of the Creative Commons Attribution (CC BY) license (http://creativecommons.org/licenses/by/4.0/). 